\title{
Short-term movement patterns, population estimates and breeding biology of an island endemic bird, the Tristan Thrush
}

\author{
Peter G. Ryan ${ }^{1,4}$, Ben J. Dilley ${ }^{1}$, Delia Davies ${ }^{1}$, Trevor Glass ${ }^{2} \&$ Fitsum Abadi $^{3}$ \\ FitzPatrick Institute of African Ornithology, DST-NRF Centre of Excellence, University of Cape Town, South Africa. \\ Tristan Conservation Department, Edinburgh of the Seven Seas, Tristan da Cunha, United Kingdom. \\ 3 Department of Fish, Wildlife and Conservation Ecology, College of Agricultural, Consumer and Environmental Sciences, New Mexico State \\ University, Las Cruces, United States of America. \\ ${ }^{4}$ Corresponding author: pryan31@gmail.com
}

Received on 18 May 2019. Accepted on 22 October 2019.

\begin{abstract}
The Tristan Thrush Turdus eremita is the only land bird that survived human colonisation of the main island of Tristan da Cunha and is listed as "Near Threatened". Population estimates are confounded by the thrushes' inquisitive and gregarious nature as well as limited information on their movements. We report the first measures of nest densities on Nightingale Island: 6 nests.ha- ${ }^{-1}$ in Phylica arborea woodland and 4-5 nests.ha ${ }^{-1}$ in tussock habitat, which suggests that the population is approximately double the previous estimate. At Inaccessible Island, we individually color ringed 110 thrushes over two months to track their short-term movements and estimate the local population size. Individuals moved up to $950 \mathrm{~m}$ along the coast, but $96 \%$ of resightings were < $100 \mathrm{~m}$. A Bayesian data augmentation approach estimated that some 260 thrushes visited the core study area, a $200-\mathrm{m}$ stretch of cobble and boulder beach where birds come to drink, bathe and forage. This result suggests that the population on Inaccessible Island also is substantially larger than reported previously. We estimate the total population to be 8000-15,000 Tristan Thrushes. The main need is a population estimate for the nominate subspecies on the main island of Tristan.
\end{abstract}

KEY-WORDS: Turdus eremita, Inaccessible Island, Nightingale Island, Bayesian population estimate.

\section{INTRODUCTION}

The Tristan Thrush or Starchy Turdus eremita is endemic to the Tristan da Cunha Archipelago in the central South Atlantic Ocean $\left(37^{\circ} \mathrm{S} ; 12^{\circ} \mathrm{W}\right)$. Until recently it was placed in its own genus, Nesocichla, reflecting its morphological adaptations to life on oceanic islands: reduced wings, robust legs and a brush-tipped tongue adapted for lapping up egg contents (Lowe 1923, Rand 1955, Fraser et al. 1994). However, genetic sequence data suggest that it is nested within the South American radiation of Turdus thrushes (Klicka et al. 2005, Voelker et al. 2007), and like the other land birds found at Tristan (Ryan et al. 2013, Stervander et al. 2018), it probably reached the islands in the last few million years.

The thrush is the only land bird that survived human colonisation of the main island of Tristan, where a small population of the nominate subspecies persists mainly above $300 \mathrm{~m}$ elevation on the steep coastal scarps and upper plateau or "base" (Ryan 2007, BirdLife International 2017). Thrushes are common at the two uninhabited islands in the archipelago: T. e. gordoni on Inaccessible Island and T. e. procax on Nightingale Island and its offshore islets, Middle and Stoltenhoff (Elliott 1957, Richardson 1984, Ryan et al. 2011). The species is listed as "Near Threatened" globally, and although the population is thought to be stable, there is a need for up-to-date population estimates (BirdLife International 2017). Current estimates are extrapolated from crude density estimates made by field workers. In the early 1970s, Richardson (1984) suggested that there were 40 60 pairs at Tristan, $300-500$ pairs at Nightingale Island, 20-40 pairs at Middle, 10-20 pairs at Stoltenhoff and 100-500 pairs at Inaccessible Island. His estimate for Inaccessible Island was particularly crude because he was unable to spend much time on that island. Subsequent field work on Inaccessible Island in the 1980s improved the estimate there to 850 pairs (Fraser et al. 1994), giving the current total population estimate of around 6000 birds (BirdLife International 2017). Estimates to date have focused on breeding pairs because the thrushes' inquisitive and gregarious nature (e.g., Hagen 1952, Fraser $e t$ al. 1994) confounds estimates of the density of non-breeding individuals using transect or point counts.

We studied thrushes at two of the three islands in the Tristan Archipelago: on Inaccessible Island, we 
aimed to individually mark a sample of thrushes to better understand their movements and estimate their population size; and on Nightingale Island we aimed to accurately estimate nest densities and gather data on breeding phenology over three seasons of fieldwork. Lastly, we aimed to use these data to refine the population estimate of Tristan Thrushes in the archipelago.

\section{METHODS}

\section{Breeding biology and nest densities}

We recorded the contents of all nests found. Tristan Thrush nests are hard to locate during incubation and early chick stage (Fraser et al. 1994), but are conspicuous once the chicks start to beg noisily when being fed. We estimated the approximate age of chicks in nests from the nestling descriptions in Fraser et al. (1994). Authors B.J.D. and D.D. systematically recorded nests while conducting research on Nightingale Island in 2015 and 2017. Additional ad hoc observations were made by P.G.R. on Nightingale Island in October-November 2007 and Inaccessible Island in November 1999-February 2000, September-December 2004 and October-December 2009.

In 2015 and 2017, thrush nests were recorded systematically on Nightingale Island along the path from the huts to the Ponds $(1.1 \mathrm{~km})$ and in First Wood, a 4.3 ha patch of Phylica arborea woodland, which was searched intensively for nests. The pathway, which runs through tall Spartina arundinacea Tussock grassland, was used daily to reach First Wood, so most nests were found that reached the large chick stage. To estimate nest densities in Tussock grassland, we assumed the path represented a strip transect between $20-40 \mathrm{~m}$ wide (10-20 m either side of the path, 2.2-4.4 ha). All nests were within $10 \mathrm{~m}$ of the path, but the path created a favourable foraging area and might have biased the distribution of thrush nests (e.g., several pairs of Brown Skua Catharacta antarctica breed along the path, and thrushes often scavenge from carcasses of petrels killed by the skuas). We divided the path into three sections: the lower $300 \mathrm{~m}$ runs through mostly level ground close to Northern Rockhopper Penguin Eudyptes moseleyi colonies; the next $330 \mathrm{~m}$ is also mostly level ground but lacks penguin colonies, and the final $470 \mathrm{~m}$ is on sloping terrain.

\section{Resighting data at Inaccessible Island}

We ringed Tristan Thrushes on Inaccessible Island $\left(37^{\circ} 18^{\prime} \mathrm{S} ; 12^{\circ} 41^{\prime} \mathrm{W}\right)$ from 22 September to 23 November 2018, which coincides with the species' breeding season. Only females develop well-defined brood patches, and thus the sex of at least some birds could be inferred. Fledged chicks were observed from early November, but no juveniles were ringed, and thus all data refer to birds at least 1 year old. Thrushes were mainly caught with hand nets, but a few birds were caught in mist nets set for finches. Thrushes initially received two color-rings as well as a metal ring, allowing them to be identified individually without recapture. However, we ran out of distinct color combinations after ringing 110 birds, and from 09 November, birds in the study area received a metal ring only (no further thrushes were ringed outside the study area). Ringing ceased on 23 November when we ran out of metal rings, but resighting observations continued until 25 November, the day before we left the island.

Ringing and resighting effort was concentrated along a 200-m long stretch of cobble and boulder beach backed by low tussock-covered cliffs centered on Runaround Beach (Fig. 1). Several fresh-water springs and seeps emerge along the base of the cliffs in this area, attracting thrushes to drink and bathe. Thrushes also forage along the shoreline (Fraser et al. 1994, Ryan \& Dilley 2019), and are much easier to resight in this habitat than in the dense vegetation that covers most of the island. We attempted to resight color-ringed Thrushes and catch unringed individuals at Runaround Beach on 20 days from 29 September to 25 November. Most visits involved two observers, and lasted at least $2 \mathrm{~h}$. On 19 and 25 November, visits lasted $4 \mathrm{~h}$, and were divided into two sessions, recording individuals present in each 2-h period to give a total sample of 22 observation events. We calculated individual detection probabilities as the proportion of observation periods when color-ringed birds were resighted after initial ringing $(n=12-21$ observation periods).

Most sighting effort occurred along the coast. In addition to the main study area, the shoreline between Runaround Beach and Blenden Hall Bay, where there is a small research hut (Fig. 1), was checked for ringed thrushes on each visit to the study area. The coast between Tern Rock and West Point (Fig. 1) also was searched on 55 days from 22 September to 26 November, and any ringed thrushes noted. Occasional visits also were made to the accessible section of coast to Warren's Cliff, east of Runaround Beach, and between West Point and Dirleton Point (Fig. 1). On 01 December we also checked $1.7 \mathrm{~km}$ of the northeast coast between the Waterfall and north of Salt Beach.

Systematic searches for ringed thrushes away from the coast were complicated by the dense vegetation, especially on the coastal slopes. The main paths followed on the western side of the island, although the East Road was used much less than the West Road to access the plateau (Fig. 1). In addition, a few thrushes were ringed 


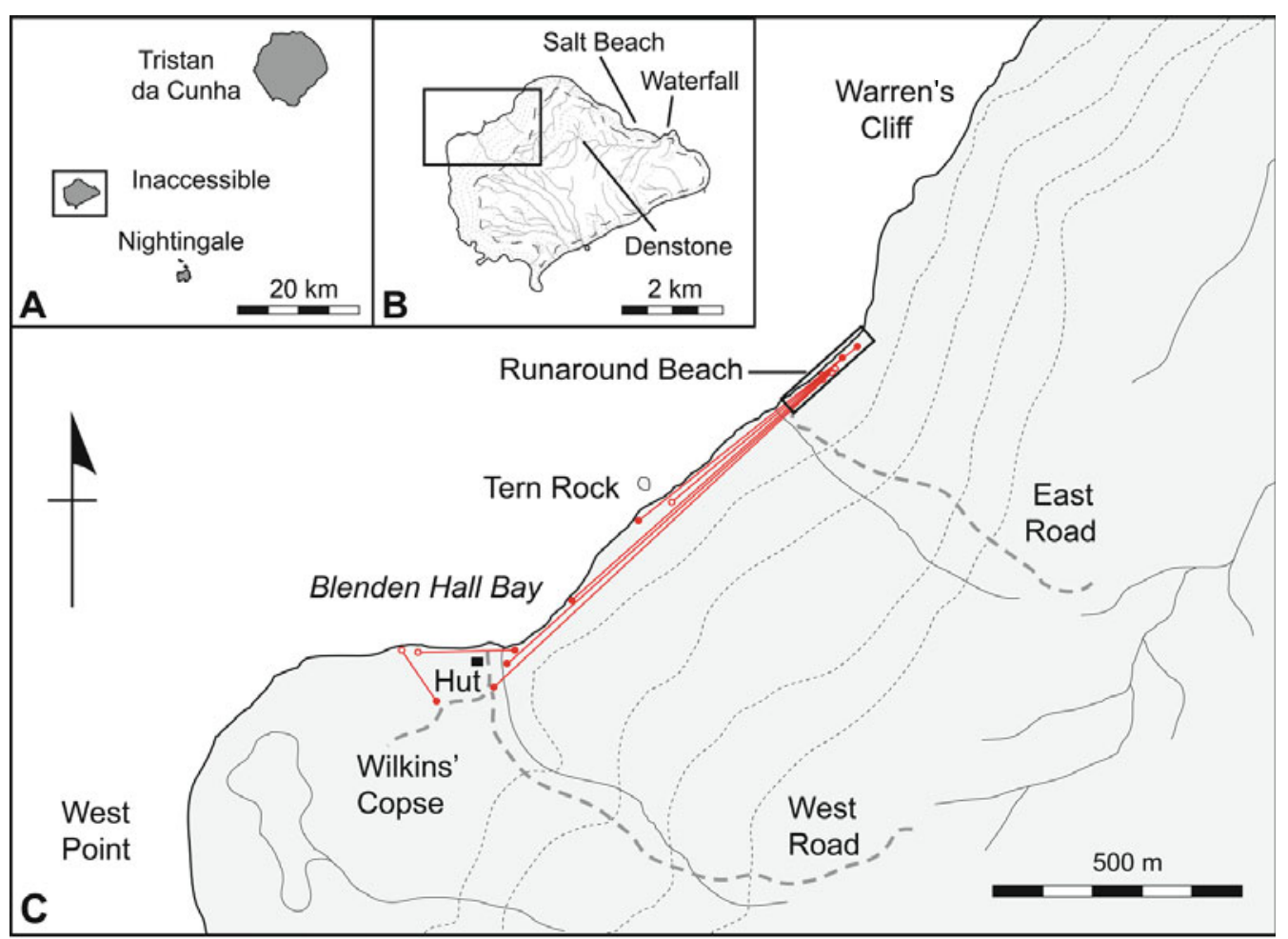

Figure 1. The Tristan Archipelago (A), Inaccessible Island (B), and main study area at Runaround Beach (black rectangle). Red lines show Tristan Thrush movements $>100 \mathrm{~m}$ (closed circle = ringing location; open circle = resighting location).

around our campsite on the eastern plateau at Denstone Junction $\left(37^{\circ} 17.61^{\prime} \mathrm{S} ; 12^{\circ} 40.43^{\prime} \mathrm{W}\right)$. All distances moved and habitat areas were estimated from Google Earth.

\section{Estimating thrush abundance}

Our initial plan was to mark 50 birds on the coast and 50 on the plateau in areas that would be visited frequently over the two months we were on the island, but it soon became apparent that the number of birds was greater than anticipated, and we focused most attention on a single coastal site where we attempted to ring as many thrushes as possible. Repeated visits to this site, coupled with regular checks along the adjacent coastline, allowed us to gauge movement distances and use a Bayesian approach to estimate the numbers of thrushes visiting the main study site. We used closed population models (Otis et al. 1978) to estimate abundance of the Tristan Thrush population at the core study area at Runaround Beach. All models were implemented using a Bayesian data augmentation approach (Royle \& Dorazio 2012), boosting the observed 147 encounter histories with a large number of individuals $(M)$ that had all-zero encounter histories. We used a hierarchical approach to describe the models. First, we used a Bernoulli distribution to determine whether an individual was a member of the true population exposed to sampling. That is,$$
Z_{i}-\operatorname{Bernoulli}(\psi)
$$

where $Z_{1}=1$, if the $i^{\text {th }}$ individual was a member of the population and 0 otherwise, and $\psi$ is the inclusion probability. The closed population $(N)$ was then estimated as the sum of $Z_{i}$ (i.e., $N=\Sigma Z_{i}$ ). Second, we modeled the encounter histories of each individual conditional on the latent variables $\left(Z_{i}\right)$ as

\section{$Y_{i t}-\operatorname{Bernoulli}\left(Z_{i} p_{i t}\right)$}

where $Y_{i t}$ if the $i^{\text {th }}$ individual was alive and detected at occasion $t$ and 0 otherwise. $p_{i t}$ is the detection probability of the $i^{t h}$ individual at occasion $t$. We imposed two possible constraints on detection probability: time and individual heterogeneity (i.e., individual variation in detection probability) (Table 1). Under $M_{r}, M_{h}$ and $M_{h t}$ models, we used a random-effect approach to model the time effect and individual heterogeneity. Hence, $\varepsilon_{t}$ and $\gamma_{i}$ are time and individual random effects, respectively. Birds marked with metal-rings only were given a detection probability of zero after first capture, because there were no resighting data for these individuals.

To implement the models in a Bayesian framework, we specified vague prior distributions for all model parameters: $\mathrm{U}(0,1)$ for $\psi, \mathrm{N}(0,0.01)$ for $\beta_{0}$, and $\mathrm{U}(0,10)$ for $\sigma_{s}$ and $\sigma_{\gamma}$. For each model, we ran three independent Markov Chain Monte Carlo (MCMC) iterations of length 100,000 with a burn-in of 50,000, and a thinning rate of 50. We used the Brooks-Gelman-Rubin $\hat{R}$ statistic (Brooks \& Gelman 1998) to assess the convergence of the 
Table 1. Models fitted to the Tristan Thrush resighting data in the core study area at Inaccessible Island, and associated DIC and $\triangle \mathrm{DIC}$ scores.

\begin{tabular}{|c|c|c|c|c|}
\hline Model & $\begin{array}{c}\text { Variation in detection } \\
\text { probability }(p)\end{array}$ & logit model for $p$ & DIC score & $\Delta \mathrm{DIC}$ \\
\hline $\mathrm{M}_{\mathrm{ht}}$ & Individual + time & $\begin{array}{c}\operatorname{logit}\left(p_{i}\right)=\beta_{o}+\varepsilon_{t}+\gamma_{i} \\
\varepsilon_{t}-N\left(0, \sigma_{\varepsilon}^{2}\right) ; \gamma_{i}-N\left(0, \sigma_{\gamma}^{2}\right)\end{array}$ & 2475.6 & 0.0 \\
\hline$M_{t}$ & Time & $\begin{array}{l}\operatorname{logit}\left(p_{i t}\right)=\beta_{o}+\varepsilon_{t} \\
\varepsilon_{t}-N\left(0, \sigma_{\varepsilon}^{2}\right)\end{array}$ & 2584.0 & 108.4 \\
\hline $\mathrm{M}_{\mathrm{h}}$ & Individual heterogeneity & $\begin{array}{c}\operatorname{logit}\left(p_{i t}\right)=\beta_{o}+\gamma_{i} \\
\gamma_{i}-N\left(0, \sigma_{\gamma}^{2}\right)\end{array}$ & 2674.2 & 198.6 \\
\hline $\mathrm{M}_{0}$ & Null & $\operatorname{logit}\left(p_{i}\right)=\beta_{0}$ & 2789.2 & 313.6 \\
\hline
\end{tabular}

MCMC chains to the targeted posterior distributions. Both the $\hat{R}$ statistic and visual inspections of the MCMC plots indicated model convergence. The model with the smallest Deviance Information Criterion (DIC; Spiegelhalter et al. 2002) was considered the best model. All analyses were performed using the JAGS software (Plummer 2003), called from R (R Core Team 2018) using the package jagsUI (Kellner 2018).

\section{RESULTS}

\section{Nest densities at Nightingale Island}

We found 60 nests over the study period. All thrush nests along the path were in Tussock stands $(n=32)$. Nests in First Wood $(n=28)$ were found in Tussock stands (9), Asplenium ferns (11), Carex sedge (5), in small rock crevices sheltered by hanging Scirpus grass (2), and in New Zealand Flax Phormium tenax (1). Flax is an invasive species at Tristan, so this nest was moved $-1 \mathrm{~m}$ to an adjacent Carex stand to allow the flax plant to be removed; the female continued to incubate, and all three eggs hatched. Tussock nests were $0.2-1.4 \mathrm{~m}$ off the ground, but other nests were within $5-10 \mathrm{~cm}$ of the ground. Eight eggs at 4 nests measured $30.7 \pm 0.8 \mathrm{~mm}(29.3-31.6 \mathrm{~mm})$ in length and $21.7 \pm 0.6 \mathrm{~mm}(20.9-22.4 \mathrm{~mm})$ in width. Clutch size at 9 nests with eggs averaged $2.1 \pm 0.6(1-3$ eggs), but some clutches may have been incomplete. Average brood size at 55 nests was $2.4 \pm 0.6$ chicks, with $51 \%$ of nests containing three chicks. The number of thrush nests found along the main path to the Ponds was 18 in 2015 and 14 in 2017, with densities tending to decrease with distance from the coast and elevation (Table 2). A total of 28 nests were found in Phylica woodland at First Wood in 2017. We were unable to tell whether any nests were repeat lays after breeding failure, but this is unlikely to greatly influence the estimate of the number of breeding pairs because few nests were found during incubation or the small chick stage, when most failures likely occur. Based on the inferred ages of chicks when nests were found, most eggs hatched from early October to late November. Our results suggest a crude density of 3-10 nests.ha ${ }^{-1}$ in tussock habitat and -6 nests. $\mathrm{ha}^{-1}$ in Phylica woodland.

\section{Movements at Inaccessible Island}

Of the color-ringed thrushes, 71 were caught at the core study site, 30 were caught farther west along the coast between Runaround Beach and Blenden Hall Bay or immediately inland around the hut (Fig. 1), and 9 were caught on the plateau (seven at Denstone Junction) or high on the West Road (two). The resighting probability of color-ringed thrushes in the core study area ranged from $0-0.83$, with $32 \%$ of birds observed on less than $10 \%$ of visits, and $85 \%$ seen on less than $50 \%$ of visits (Fig. 2). Overall, the most common number of resightings was 0 (Fig. 1 in Appendix I), even though most color ringing away from the study area ceased in mid-October, allowing more than a month for ringed birds to be resighted. A few birds were seen regularly in the same area. Some of these birds held breeding territories and subsequently were seen with fledglings, whereas others seemingly were non-breeders that foraged along the shoreline (see Ryan \& Dilley 2019). Most non-breeders remained on more or less the same stretch of coast throughout, but one bird moved $\sim 120$ m west midway through the study period, remaining in this new site until we left the island.

The pattern of a few resident individuals and larger numbers of transient birds was obvious at the hut, where catching and resighting effort was arguably greatest. Fourteen thrushes were caught at the hut. Of these, one pair of birds was resident, being seen virtually every day ranging $50 \mathrm{~m}$ between the hut and the adjacent coast; this pair nested in dense tussock next to the beach in front of the hut. Of the remaining 12 thrushes, one was seen regularly in Blenden Hall Bay, $90 \mathrm{~m}$ from the hut, two were resighted once in the core study area $(-950 \mathrm{~m}$ from the hut; resighted 28 and 32 days after ringing), one 
Table 2. Numbers of Tristan Thrush nests in Tussock grassland along the path from the huts to First Wood on Nightingale Island in 2015 and 2017.

\begin{tabular}{|c|c|c|c|c|}
\hline \multirow{2}{*}{ Habitat } & \multirow{2}{*}{ Distance } & \multicolumn{2}{|c|}{ Number of nests } & \multirow{2}{*}{$\begin{array}{c}\text { Density* }^{*} \\
\left(\text { nests.ha }^{-1}\right)\end{array}$} \\
\hline & & 2015 & 2017 & \\
\hline $\begin{array}{l}\text { Level ground with } \\
\text { penguins }\end{array}$ & $300 \mathrm{~m}$ & 8 & 5 & $5.4-10.8$ \\
\hline $\begin{array}{l}\text { Level ground, no } \\
\text { penguins }\end{array}$ & $330 \mathrm{~m}$ & 4 & 6 & $3.8-7.6$ \\
\hline Sloping ground & $470 \mathrm{~m}$ & 6 & 3 & $2.4-4.8$ \\
\hline
\end{tabular}

*assumes average number of nests and strip transect $20-40 \mathrm{~m}$ wide; see methods for further details.

was seen once in Phylica trees $20 \mathrm{~m}$ behind the hut (44 days after ringing), and the other 8 were not seen again. A similar pattern also occurred at the plateau camp, although only 7 thrushes were ringed here: 2 were seen on most visits to the camp, 1 was seen once (recaptured in a mist net the day after initial capture), and 4 were not seen again.

Most resightings were within $100 \mathrm{~m}$ of the original ringing site ( $96 \%, n=427$ of 446 ). However, we frequently observed thrushes making flights $>100 \mathrm{~m}$, mainly along the shore. One male that defended a territory at the western edge of the study area frequently chased birds out of sight along the coast to the west (at least $200 \mathrm{~m}$ ), but was not observed outside the study area. The maximum movement distance recorded was $950 \mathrm{~m}$, from the hut to the core study area $(n=2)$. Two other birds ringed in Blenden Hall Bay moved as far as the study area (700$900 \mathrm{~m}$ ), and 1 ringed near Tern Rock also was seen in the core study area $(500 \mathrm{~m})$. The farthest movement of birds ringed in the study area was to the Tern Rock area (400-500 m, $n=4$ of 71 birds). No ringed birds were seen inland from the study area, but access to the dense Spartina tussock in this area was restricted to the East Road, which was only visited a few times. In the more accessible Blenden Hall area, one thrush caught in a mist net midway between the hut and Wilkins' Copse, $130 \mathrm{~m}$ inland (Fig. 1), was subsequently seen regularly on the adjacent coast.

\section{Thrush numbers in the study area at Inaccessible Island}

The population estimate for the core study area was based on encounter histories for 76 color-marked thrushes (71 ringed at the site and 5 birds ringed along the adjacent coast as far west as the hut) and 71 metal-only ringed birds caught at the study sight after we ran out of color combinations. Average resighting rate of the 76 ringed thrushes in the 12 2-h observation periods in the core study area after color-ringing ceased was $29 \pm 6 \%(21-$ $38 \%)$. The model including individual heterogeneity and a time effect $\left(\mathrm{M}_{\mathrm{h}}\right)$ provided the best fit to the resighting data (Table 1). The posterior mean thrush population visiting Runaround Beach under this model was -258 birds (95\% credible interval, CRI: 212-314), and this estimate was largely independent of $M$, providing $M$ $\geq 200$ (Table 1 in Appendix I, Fig. 2 in Appendix I). The rate at which thrushes were ringed at the study site showed no evidence of decreasing over time (Fig. 3), supporting the large population estimate for the site. The posterior mean detection probability was 0.031 (95\% CRI: 0.016-0.053), and posterior estimates for $\sigma_{\varepsilon}$ and $\sigma_{\gamma}$ were $0.91(0.63-1.29)$ and $1.92(1.57-2.39)$, respectively, confirming the considerable temporal and individual variation in detection probability.

\section{DISCUSSION}

The main challenge to estimating the population size of Tristan Thrushes is their inquisitive nature. As Hagen (1952) noted "they immediately fly to meet every new thing", including people. As a result, any attempt to estimate the population density by random transects or point counts is confounded by the unknown radius over which thrushes are attracted. Individually marking thrushes does not directly solve this problem, because the act of catching and ringing the birds makes them more cautious around people (Fraser et al. 1994, pers. obs.). Current population estimates are crudely estimated from the approximate density of breeding pairs (Richardson 1984, Fraser et al. 1994). Richardson (1984) estimated $300-500$ pairs on Nightingale Island, but our observations show that this is conservative.

We present the first estimates of nest densities for Tristan Thrushes. On Nightingale Island, the estimate for Phylica woodland at First Wood (6 nests.ha $\left.{ }^{-1}\right)$ is likely to be fairly accurate, as the entire area was searched intensively. It is likely that some thrushes re-lay if their initial breeding attempt fails but this is unlikely to have inflated the nest count because most nests were only recorded at the chick stage and there is no indication of double brooding (the breeding season is short, with adults starting to moult from late November while still 
feeding fledged chicks; Fraser et al. 1994). Estimating nest density for tussock habitat is complicated by the fact that the path is not a random transect through this habitat. However, incidental observations made while walking through tussock away from the path suggest that the density of thrush nests along the path is not atypical, and a density of $4-5$ nests.ha ${ }^{-1}$ is thought to be a reasonable average across the island. Extrapolating these densities based on the total area of each habitat at Nightingale Island (160 ha tussock and 11 ha woodland) suggests a population of some $700-850$ breeding pairs, roughly double that estimated by Richardson (1984). This number of breeding pairs suggests a total population of 2000-3500 thrushes on Nightingale Island, including pre-breeders (few if any thrushes breed until they are at least two years old, Hagen 1952).

Our breeding observations confirm that clutch sizes on Nightingale Island are consistently larger than those on Inaccessible Island. Roughly half of all broods on Nightingale were of three chicks, whereas three-egg clutches have not been recorded on Tristan or Inaccessible Island (Elliott 1957, Richardson 1984, Fraser et al. 1994, P.G.R. unpub. data). Quite what causes this difference is not known. Elliott (1957) reported that eggs of T. e. procax on Nightingale Island were larger than those of T. $e$. gordoni on Inaccessible Island, but our egg measurements at Nightingale averaged smaller $(30.7 \times 21.7 \mathrm{~mm})$ than those reported by Elliott (1957) of $33.5 \times 22.7 \mathrm{~mm}$.

Thrush densities are thought to be lower at Inaccessible than at Nightingale Island. Fraser et al. (1994) estimated thrushes occurred at 1.0 pair.ha ${ }^{-1}$ in tussock grassland, and $0.2-0.8$ pairs. $^{-1} \mathrm{a}^{-1}$ in three habitats on the island plateau. However, densities are hard to assess, particularly along the coastal cliffs where nests are concealed in the densest, most inaccessible Tussock grass (Fraser et al. 1994), and as on Nightingale Island, probably are conservative estimates. We attempted to gain an independent estimate of thrush density by colorringing a large sample of birds at Inaccessible Island. Our results support previous records on the movement of ringed Tristan Thrushes. The 36 thrushes color-ringed at Inaccessible Island in 1982/83 were largely sedentary, with regular movements of around $250 \mathrm{~m}$ between the hut and Wilkins' Copse, and a maximum movement of $800 \mathrm{~m}$ (Fraser et al. 1994). Similarly, of the "nearly 100" thrushes Elliott (1957) ringed at the landing area on Nightingale Island, none was resighted more than $300 \mathrm{~m}$ away, suggesting they seldom undertake large movements. However, 2 of the 5 color-ringed birds resighted at Inaccessible Island from 1987-1989/90 were observed only once over the three seasons (Fraser et al. 1994), suggesting that they are not regular visitors to areas accessible to observers. Our results confirm that individual variation in resighting rates is characteristic of this species. Despite ample opportunities for birds to be resighted, and high resighting rates for some individuals, the most common result was for color-ringed birds to be not seen again (Fig. $2 \&$ Fig. 1 in Appendix I). More observations are needed to assess whether such birds remain in areas of dense tussock, not readily accessible to observers, or are more vagile. Until this conundrum is resolved, we will struggle to derive accurate population estimates.

Despite the issue of possible transient birds, the number of thrushes caught at the core study site at Inaccessible Island was impressive, with no decrease in the rate at which unringed birds were caught over 2 months (Fig. 3). In fact, the proportion of unringed birds caught

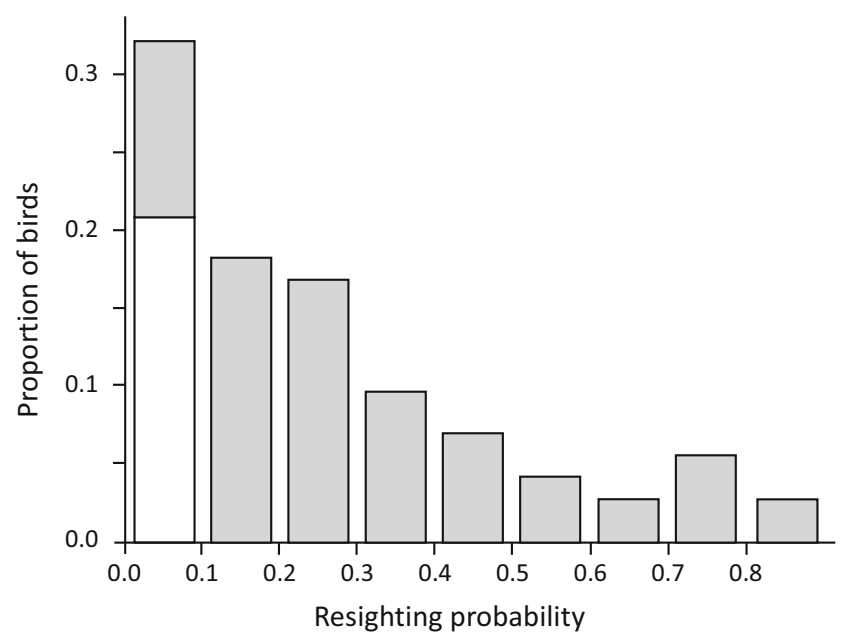

Figure 2. The probability that a Tristan Thrush color-ringed in the core study area was resighted in subsequent visits (white = 0 probability; $n=71$ ).

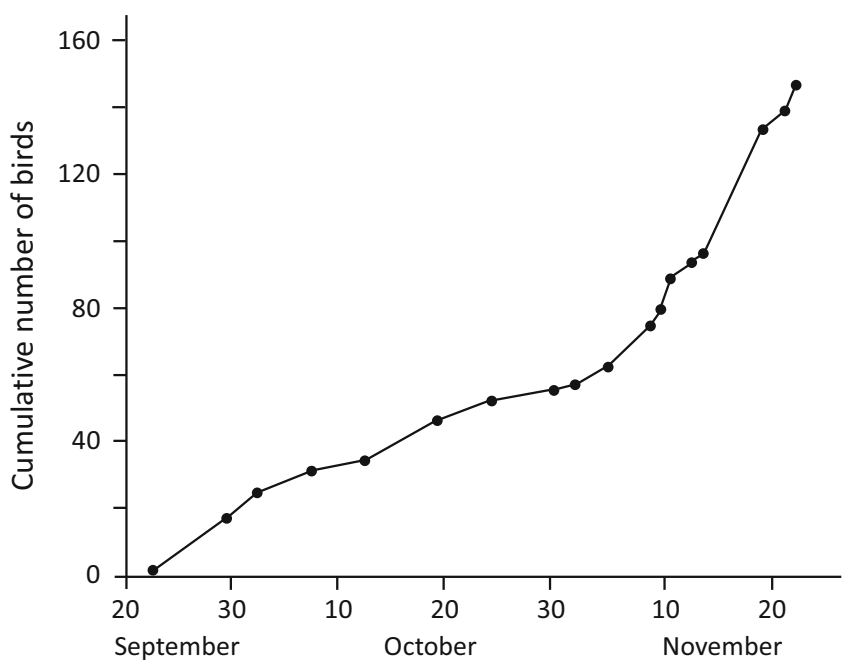

Figure 3. The cumulative number of Tristan Thrushes ringed at the core study area from 22 September to 23 November 2018. Color-ringing ceased from 09 November, making it faster to process birds and thus increasing the catch rate. 
decreased over the course of the study, as individuals became more wary of being approached with a hand net - had this not been the case, even more birds would have been caught later in the study. On the final day of observations (25 November) we estimated that there were almost as many unringed birds as there were colorringed and metal-only birds, which lends credence to the Bayesian estimate of around 260 birds visiting the study site. If we assume that thrushes from the lower half of the coastal cliffs (i.e., up to $c$. $200 \mathrm{~m}$ elevation) visit the core study site, and travel up to $500 \mathrm{~m}$ along the coast (likely a minimum estimate, given the limited movement of most birds), then the population at the site represents birds from a catchment area of around 20 ha. Increasing the radius along shore to the maximum movement recorded would increase this to around 40 ha. These catchment areas give a density of 6.5-13 thrushes ha $^{-1}$, which if extrapolated across the coastal scarp (500 ha), suggests a population of roughly 3250-6500 fully grown thrushes. The density on the plateau (1000 ha) is perhaps $1 / 3$ to $1 / 2$ that along the coast (Fraser $e$ t al. 1994), giving a crude population of 5500-11,000 thrushes on Inaccessible Island.

Elliott (1957) does not specify the period over which he ringed "nearly 100 " thrushes in the immediate vicinity of the landing-place on Nightingale Island, but his experience mirrors ours on Inaccessible Island, and supports our inference of a large thrush population from nest densities on Nightingale Island. Combined with recent estimates of thrush populations on Middle (5-10 pairs) and Stoltenhoff Islands (10-20 pairs; Ryan et al. 2011) and "hundreds" on Tristan da Cunha Island (BirdLife International 2017), we estimate the total population to be 8000-15,000 Tristan Thrushes. Although this increases the global population, we recommend the species status should remain as "Near Threatened" globally. A more accurate estimate of the tiny population on Tristan is a conservation priority.

\section{ACKNOWLEDGEMENTS}

We thank the Island Council and Administrator for approving our visit to Inaccessible Island. Maëlle Connan and Erica Sommer gave assistance in the field. Funding for land bird surveys at Tristan was received from Darwin Plus. The South African National Antarctic Programme provided logistical support, and we are especially grateful to the captain and crew of the "Geo Searcher" for getting us safely off the island. We thank William R. Gould for helpful discussions on the statistical analysis. Fitsum Abadi thanks The New Mexico Agricultural Experiment Station (NM Fitsum-2017H).

\section{REFERENCES}

BirdLife International. 2017. The IUCN red list of threatened species Turdus eremita. e.T22708541A117286443 (Access on 25 April 2019).

Brooks S.P. \& Gelman A. 1998. General methods for monitoring convergence of iterative simulation. Journal of Computational and Graphical Statistics 7: 434-455.

Elliott H.F.I. 1957. A contribution to the ornithology of Tristan da Cunha group. Ibis 99: 545-586.

Fraser M.W., Ryan P.G., Dean W.R.J. Briggs, D.J. \& Moloney C.L. 1994. Biology of the Tristan Thrush Nesocichla eremita. Ostrich 65: 14-25.

Hagen Y. 1952. The birds of Tristan da Cunha. Results of the Norwegian Expedition to Tristan da Cunha 1937-1938. 20: 1-248.

Kellner K. 2018. jagsUI: a wrapper around 'rjags' to streamline 'JAGS' analyses. R package version 1.5.0.

Klicka J., Voelker G. \& Spellman G.M. 2005. A molecular phylogenetic analysis of the "true thrushes" (Aves: Turdinae). Molecular Phylogenetics and Evolution 34: 486-500.

Lowe P.R. 1923. Notes on some land birds of the Tristan da Cunha group collected by the 'Quest' Expedition. Ibis 65: 511-528.

Otis D.L., Burnham K.P., White G.C. \& Anderson D.R. 1978. Statistical inference from capture data on closed animal populations. Wildlife Monographs 62: 1-135.

Plummer M. 2003. JAGS: a program for analysis of Bayesian graphical models using Gibbs sampling. Vienna: Proceedings of the $3^{\text {rd }}$ International Workshop on Distributed Statistical Computing (DSC 2003).

R Core Team 2018. R: a language and environment for statistical computing. Vienna: R Foundation for Statistical Computing.

Rand A.L. 1955. The origin of the land birds of Tristan da Cunha. Fieldiana Zoology 37: 139-166.

Richardson M.E. 1984. Aspects of the ornithology of the Tristan da Cunha group and Gough Island, 1972-1974. Cormorant 12: 123-201.

Royle J.A. \& Dorazio R.M. 2012. Parameter-expanded data augmentation for Bayesian analysis of capture - recapture models. Journal of Ornithology 152: S521-S537.

Ryan P.G. 2007. Field guide to the animals and plants of Tristan da Cunha and Gough Island. Newbury: Pisces Publications.

Ryan P.G. \& Dilley B.J. 2019. Intertidal foraging by Tristan Thrushes. Ostrich 90: 179-181.

Ryan P.G., Glass N. \& Ronconi R.A. 2011. The plants and birds of Stoltenhoff and Middle Islands, Tristan da Cunha. Polar Record 47: 86-89.

Ryan P.G., Klicka L.B., Barker F.K. \& Burns K.J. 2013. The origin of finches on Tristan da Cunha and Gough Island, central South Atlantic Ocean. Molecular Phylogenetics and Evolution 69: 299305 .

Spiegelhalter D.J., Best N.G., Carlin B.R. \& van der Linde A. 2002. Bayesian measures of model complexity and fit. Journal of the Royal Statistical Society, Series B: Statistical Methodology 64: 583-616.

Stervander M., Ryan P.G., Melo M. \& Hansson B. 2018. The origin of the world's smallest flightless bird, the Inaccessible Island Rail Atlantisia rogersi (Aves: Rallidae). Molecular Phylogenetics and Evolution 130: 92-98.

Voelker G., Rohwer S., Bowie R.C.K. \& Outlaw D.C. 2007. Molecular systematics of a speciose, cosmopolitan songbird genus: defining the limits of, and relationships among, the Turdus thrushes. Molecular Phylogenetics and Evolution 42: 422-434.

Associate Editor: Lilian T. Manica. 
Table 1. The estimated population size ( $n$ ) of Tristan Thrushes in the core study area as a function of M, the number of augmented individuals that had all-zero encounter histories.

\begin{tabular}{cc}
\hline $\mathbf{M}$ & $\boldsymbol{n}(\mathbf{9 5} \%$ credible interval $)$ \\
\hline 50 & $193(183-197)$ \\
100 & $233(206-247)$ \\
150 & $256(212-293)$ \\
200 & $258(212-309)$ \\
300 & $258(212-314)$ \\
500 & $259(212-312)$ \\
1000 & $259(214-313)$ \\
\hline
\end{tabular}

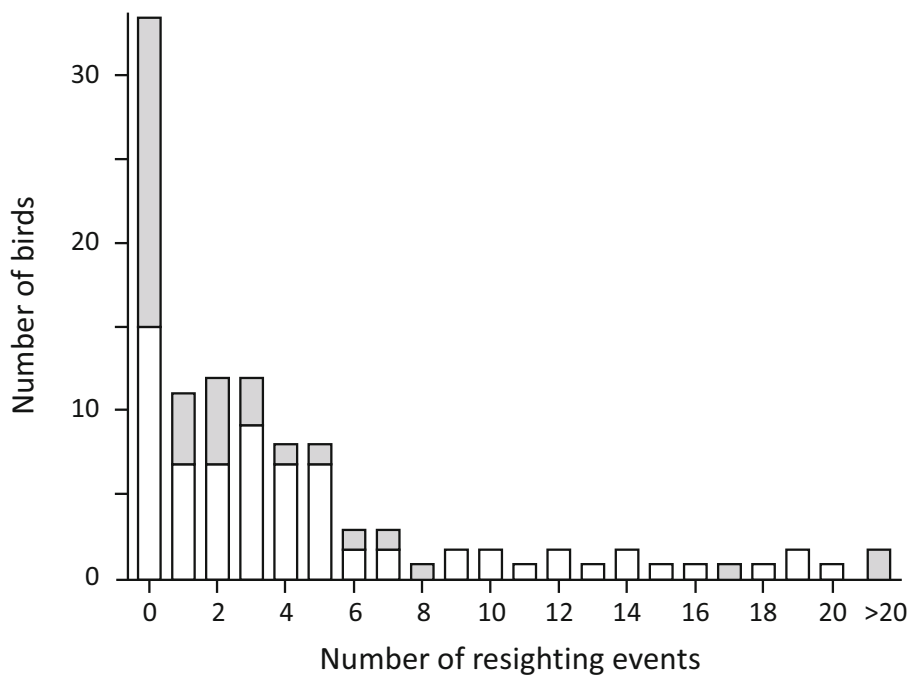

Figure 1. The frequency distribution of the number of times color-ringed Tristan Thrushes were resighted at Inaccessible Island in 2018 (white $=$ birds ringed in the core study area; grey $=$ other areas).
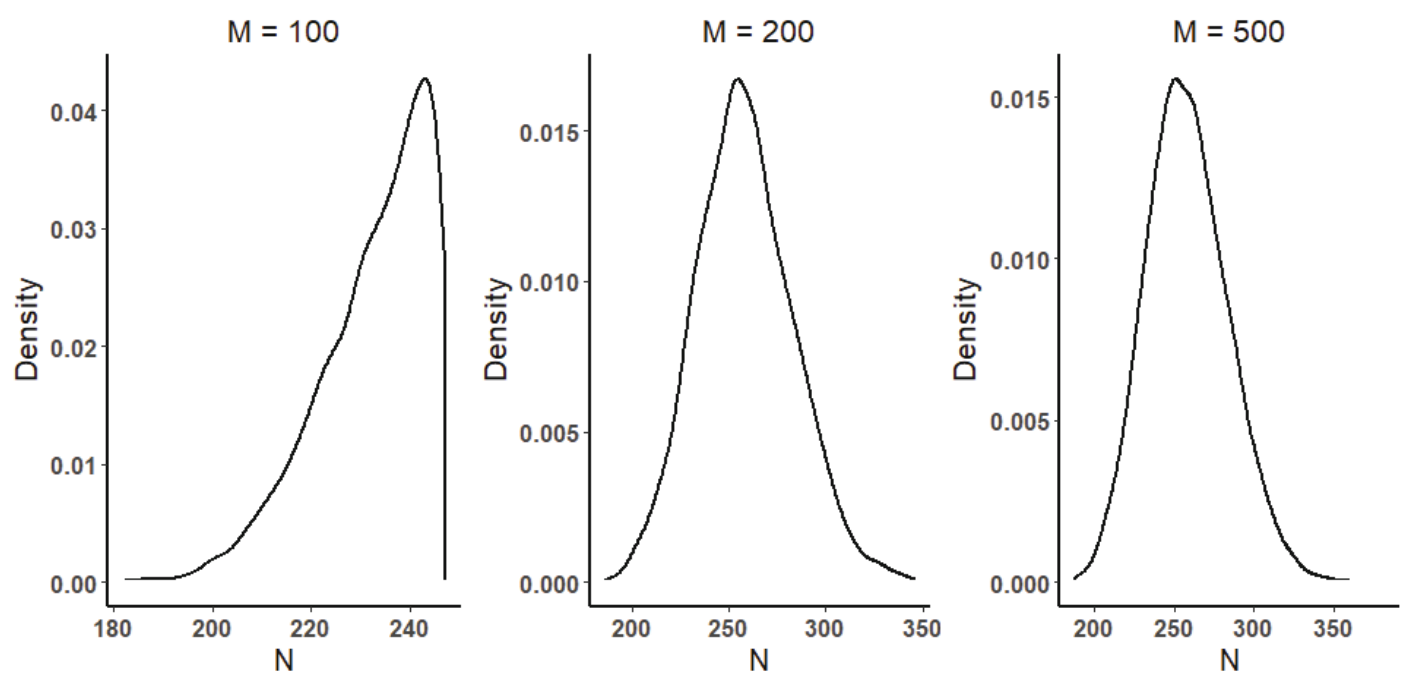

Figure 2. Posterior distributions of Tristan thrush abundance $(\mathrm{N})$ from the best model $\left(\mathrm{M}_{\mathrm{ht}}\right)$, under different values of $\mathrm{M}$. The posterior distribution of $\mathrm{N}$ was not right truncated for $\mathrm{M} \geq 200$. 